\title{
A large abandoned cellar as roost for bats in western Romania
}

\author{
RICHARD HOFFMANN1 \\ MIHAELA UNGUREANU2 \\ SEVERUS-DANIEL COVACIU-MARCOV ${ }^{3}$ * \\ ${ }^{1}$ Crocna, No 216, 317117, Arad County, Romania \\ 2 University of Oradea, Faculty of Geography \\ Tourism and Sport, Department of Geography, \\ Tourism and Territorial Planning; 1, Universităţii, \\ Oradea 410087, Romania \\ ${ }^{3}$ University of Oradea, Faculty of Sciences, \\ Department of Biology; 1, Universităţii, \\ Oradea 410087, Romania \\ * Correspondence: \\ e-mail: severcovaciu1@gmail.com
}

Keywords: artificial roosts, habitats, plains, cave-dwelling bats.

Received March 20, 2016

Revised June 21, 2016.

Accepted June 23, 2016.

\section{Abstract}

Background and Purpose: Artificial structures and shelters are in some cases important for bats. In Romania there are many data about the natural roosts used by bats, which are generally related with mountains, where caves shelter large colonies. The information about artificial roosts is brief.

Materials and Methods: Field observations were made in the winter of the years 2015 / 2016, in an abandoned wine cellar, near Mocrea locality, western Romania. The bats were directly observed and numbered. The cellar was identified accidentally.

Results: Miniopterus schreibersii, Rhinolophus ferrumequinum and Myotis myotis were found in 2015 / 2016 winter in an abandoned wine cellar from Mocrea. M. schreibersii has the largest colony. The number and location of bat species and individuals in the cellar changed during the winter.

Conclusions: The three cave dwelling bat species identified in the cellar use this artificial roost because in the region there are no natural caves. Even in a country with many natural roosts, artificial underground habitats can be important for cave dwelling bats.

\section{INTRODUCTION}

The information upon bats distribution in Romania is not uniform

1 in the country's regions (see in: 1). Many species are related with the Romanian mountains, where caves shelter hibernating or nursing colonies (e.g. 2, 3, 4, 5, 6). Their distribution differs between the countries' mountains (4), many caves being in western Romania, in Apuseni Mountains (e.g. 4, 5). Sometimes bats can use artificial structures and shelters (e.g. 7, 8, 9, 10). In Romania, although there are many data about the natural roosts used by bats (e.g. 2, 3, 5, 6, 11), the information about the artificial ones are very few (12). In this context, we aimed to present information about an artificial roost used by three bat species in western Romania.

\section{MATERIAL AND METHODS}

Field observations took place in 15 October, 6 November 2015, 11 and 30 January and 4 March 2016. The bats were encountered in an abandoned large wine cellar, situated in Mocrea locality, in Arad County, western Romania. The cellar was identified accidentally, during a study dedicated to western Romanian vineyards. The cellar is situated in the first hill which borders from east the Crișuri Plain, neighboring with flat agricultural plains to the west and with low hills with oak forest to the east. In the region there are water courses and stagnant waters. The cellar 
entrance is masked by abandoned buildings. It consists from five perpendicular tunnels (two / three), with more that $3 \mathrm{~m}$ height and more that $2 \mathrm{~m}$ width, with closed ends. The bats were directly observed and numbered, not being handled. We also used a heterodyne bat detector type (Pettersson 240 D). We have observed the locations used by bats in the summer after the trails on the walls or guano.

\section{RESULTS}

In the cellars from Mocrea we identified more than 4000 individuals belonging to three bat species: Miniopterus schreibersii, Rhinolophus ferrumequinum and Myotis myotis. The most common was $M$. schreibersii. M. myotis was recorded only from January to March. Both the number of individuals and their position in the cellar differed in time (Table 1). M. schreibersii colony (Fig 1) occupied the end of a tunnel, in 15 October being represented by more than 4000 individuals, dropping to the end of January to only 77 individuals. In the first two dates the colony occupied the same tunnel. In January the location was changed, probably because of humans, who make fire in the vicinity of the first locations. $R$. ferrumequinum individuals were not grouped, isolated individuals being observed in different points of the cellar. Bat continues presence in the cellar in the winter is confirmed by the two extremely cold periods from January, when the diurnal temperatures were negative for many consecutive days. In the summer the cellar seems even more intensely used by bats, judging by the guano deposits from three different place of the cellar.

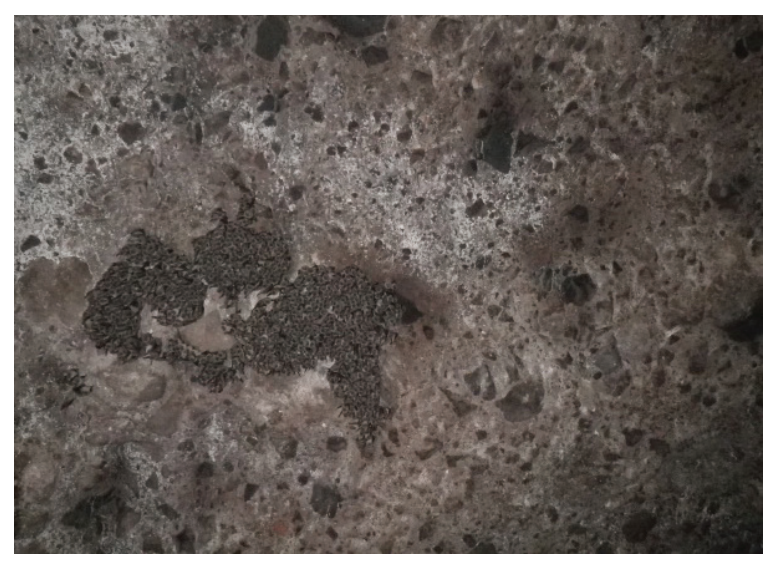

Fig. 1 M. schreibersii winter colony in the Mocrea cellar

\section{DISCUSSIONS}

The bat species from Mocrea cellar are well represented in western Romania (e.g. 13), being frequently recorded in caves from Apuseni Mountains (e.g. 4, 5, 11). M. schreibersii has big populations in more caves from the region, even if it seems to be in decline $(4,5)$. At Mocrea it benefits by the presence of many stagnant and flowing waters. $M$. schreibersii hunt in areas with waters (14), traveling large distances for feeding (15). In other areas this species was also observed at the entrance of an abandoned wine cellar (16) and in other artificial habitats $(15,17)$. The information scarcity regarding the use of artificial roosts by bats in Romania is probably a consequence of the existence of many natural roosts that shelter large bat populations (e.g. 2, 3, 4, 5). At Mocrea, bats do not use the cellar because the natural underground roosts were affected, but because their absence from the region. The region neighboring the cellar is generally a flat plain, used for agriculture. In such a landscape, cave dwelling bats can not have winter or summer roosts. The species identified in the cellar are cave dwelling species (e.g. 13), even if sometimes they were recorded in open plains (e.g. 18). R. ferrumequinum dependence from subterranean roosts was observed in other cases, the north-western Hungarian populations hibernating in underground roosts from Slovakia (19). Thus, the cellar from Mocrea offers an underground habitat to some bat species that use the plains as a hunting ground, but depend on subterranean roosts.

Although the bat species from Mocrea are protected (20) and present in a protected area, they are subject to human pressure. In January the bats were disturbed by humans, who make a fire near the colony. Judging by the fire marks, these incidents are relatively frequent in the cellar. Human activity, represented by creation of the cellar, initially favored the bats, allowing the presence of cave species in an area without caves. Nevertheless, human activity has also a negative impact on bats. Artificial underground roosts, like the one from Mocrea, can explain in other cases too the presence of cave dwelling bats in plain areas without caves (18). The bats from Mocrea indicate that even in a country with many natural roosts, the artificial underground habitats can be advantageous for cave dwelling bats. Thus, this type of habitats deserves a better attention in bat studies.

Table 1 Bat species presence in Mocrea cellar

\begin{tabular}{|c|c|c|c|c|c|}
\hline Species & October 15, 2015 & November 6, 2015 & January 11, 2016 & January 30, 2016 & March 4, 2016 \\
\hline M. schreibersii & $>4000$ & 610 & 95 & 77 & 230 \\
\hline R. ferrumequinum & 3 & 7 & 10 & 9 & 8 \\
\hline M. myotis & - & - & 1 & 2 & 1 \\
\hline
\end{tabular}




\section{REFERENCES}

1. UHRIN M, BENDA P, LUČAN R, MIKOVÁ E, RENDOŠ M, HORÁČEK I 2014 Noteworthy bat records from Romania. Vespertilio 17: 197-213

2. DRAGU A 2009 Species structure of the bat community hibernating in Muierilor Cave (Southern Carpathians, Romania). NorthWest J Zool 5(2): 281-289

3. MURARIU D, GHEORGHIU V 2010 Şura Mare Cave (Romania), the most important known hibernating roost for Pipistrellus pygmaeus Leach, 1825 (Chiroptera: Vespertilionidae). Travaux du Muséum Natioal d'Histoire Naturelle "Grigore Antipa» 53: 329338 http://dx.doi.org/10.2478/v10191-010-0023-6

4. NAGY Z, POSTAWA T 2011 Seasonal and geographical distribution of cave-dwelling bats in Romania: implications for conservation. Anim Conserv 14: 74-86 http://dx.doi.org/10.1111/j.1469-1795.2010.00392.x

5. BÜCS S, JÉRE C, CSŐSZ I, BARTI L, SZODORAY-PARÁDI F 2012 Distribution and conservation status of cave-dwelling bats in the Romanian Western Carpathians. Vespertilio 16: 97-113

6. CSÖSZ I, JÉRE C, BÜCS S, BARTHA C, BARTI L, SZODORAY-PARÁDI F 2015 The presence of Mehely's horseshoe bar Rhinolophus mehelyi in South-western Romania. North-West J Zool 11(2): 351-356

7. BIHARI Z 1998 Examination of the settlement of Myotis myotis in an abandoned mine. Myotis 36: 225-228

8. AMORIM F, ALVES P, REBELO H 2013 Bridges over the troubled Conservation of Iberian Bats. Barbastella 6(1): 3-12

9. KURTA A, SMITH SM 2014 Hibernating Bats and Abandoned Mines in the Upper Peninsula of Michigan. Northeastern Naturalist 21(4): 587-605 http://dx.doi.org/10.1656/045.021.0407

10. VINTULIS V, PËTERSONS G 2014 Root cellars are important winter roosts for brown long-eared bats (Plecotus auritus) and northern bats (Eptesicus nilssonii) in Latvia. Mammalia 78(1): 8591 http://dx.doi.org/10.1515/mammalia-2012-0104
11. MĂRGINEAN G, HOFFMANN R, IANC R 2011 New data regarding the bat (Mammalia: Chiroptera) species distribution in western Romanian cave roosts. Brukenthal Acta Musei 6(3): 499510

12. POCORA I, POCORA V, BALTAG E 2008 The structure and dynamics of a hibernation mixed colony of bats (Chiroptera) from an old galley mine (Rarău Mountains - Romania). Analele Științifice ale Universității „Al. I. Cuza” Iași, s. Biologie animală 54: $227-435$

13. MURARIU D 2005 Mammalia (Mamifere). În: Cartea Roşie a Vertebratelor din România, editori: Botnariuc \& Tatole. Ed. Academiei Române, Bucharest. [in Romanian].

14. RUSSO D, JONES G 2003 Use of foraging habitats by bats in a Mediterranean area determined by acoustic surveys: conservation implications. Ecography 26: 197-209 http://dx.doi.org/10.1034/j.1600-0587.2003.03422.x

15. VINCENT S, NEMOZ M, AULAGNIER S 2011 Activity and foraging habitats of Miniopterus schreibersii (Chiroptera, Miniopteridae) in southern France: implications for its conservation. Hystrix It J Mamm 22 (1): 57-72

16. DANKO S, PJENČĆK P 2006 Výskyt lietavca st’ahovavého (Miniopterus schreibersii) v Slanských vrchoch. Vespertilio 9-10: 222-224

17. PRESETNIK P 2004 Bat species and conservation issues in the castle Grad na Goričkem (NE Slovenia). Mammalia 68(4): $437-$ 435 http://dx.doi.org/10.1515/mamm.2004.043

18. HOFFMANN R, HOFFMANN-BEREI I 2014 Preliminary data on the bat fauna from Carei Plain natural protected area, Romania. North-West J Zool 10(Supplement1): S27-S32

19. BIHARI Z 2001 Characteristics on northernmost population of Rhinolophus ferrumequinum in the Carpathian Basin. Acta Theriol 46(1): 13-21 http://dx.doi.org/10.1007/BF03192412

20. ${ }^{* * * * *}$ O.U.G. nr. 57 / 2007 privind regimul ariilor naturale protejate, conservarea habitatelor naturale, a florei şi faunei sălbatice. [in Romanian]. 
